APPLICATIONS OF

\title{
AEROSPACE
}

TECHNOLOGY

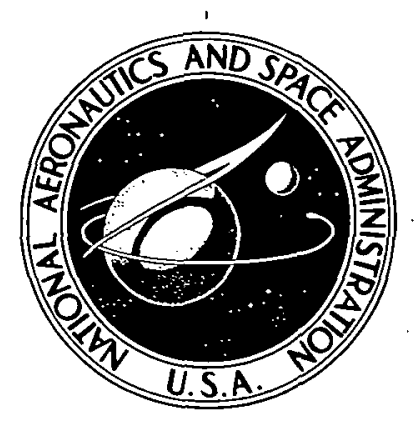

NASA CR-2505

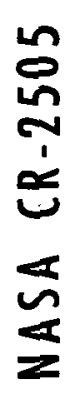

\section{POLAROGRAPHIC OXYGEN SENSORS}

Prepared by

MIDWEST RESEARCH INSTITUTE

Kansas City, Mo. 64110

for Technology Utilization Office

NATIONAL AERONAUTICS AND SPACE ADMINISTRATION - WASHINGTON, D. C. - JANUARY 1975 


\begin{tabular}{|c|c|c|c|}
\hline $\begin{array}{l}\text { 1. Report No. } \\
\text { CR-2505 }\end{array}$ & 2. Government Accession No. & \multicolumn{2}{|c|}{ 3. Recipient's Catalog No. } \\
\hline \multirow{2}{*}{\multicolumn{2}{|c|}{$\begin{array}{l}\text { 4. Title and Subtitle } \\
\text { FOIAROGRAPHIC OXYGEN SENSORS }\end{array}$}} & \multicolumn{2}{|c|}{$\begin{array}{l}\text { 5. Report Date } \\
\text { January } 1975\end{array}$} \\
\hline & & \multicolumn{2}{|c|}{ 6. Performing Organization Code } \\
\hline \multirow{2}{*}{ 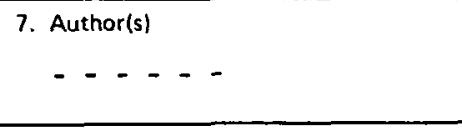 } & & \multicolumn{2}{|c|}{ 8. Performing Organization Report No. } \\
\hline & & \multirow{2}{*}{\multicolumn{2}{|c|}{ 10. Work Unit No. }} \\
\hline \multirow{2}{*}{\multicolumn{2}{|c|}{$\begin{array}{l}\text { MIDWEST RESEARCH INSTITUTE } \\
425 \text { Volker Boulevard } \\
\text { Kansas City, MO } 64110\end{array}$}} & & \\
\hline & & \multicolumn{2}{|c|}{$\begin{array}{l}\text { 11. Contract or Grant No. } \\
\text { NASW }-2454\end{array}$} \\
\hline \multirow{2}{*}{\multicolumn{2}{|c|}{$\begin{array}{l}\text { 12. Sponsoring Agency Name and Address } \\
\text { National Aeronautics and Space Administration } \\
\text { Washingtion, DC } 20546\end{array}$}} & \multicolumn{2}{|c|}{$\begin{array}{l}\text { 13. Type of Report and Period Covered } \\
\text { Contrector Report }\end{array}$} \\
\hline & & \multicolumn{2}{|c|}{$\begin{array}{c}\text { 14. Sponsoring Agency Code } \\
\text { KT }\end{array}$} \\
\hline \multicolumn{4}{|c|}{ EEPORT -- SECTION I, April 30, 1974} \\
\hline \multicolumn{4}{|l|}{$\begin{array}{l}\text { 16. Abstract } \\
\text { Early biomedical studi } \\
\text { instruments which could holo } \\
\text { available. } \\
\text { The new membrane-type } \\
\text { of oxygen in gas mixtures a }\end{array}$} \\
\hline $\begin{array}{l}\text { 17. Key Words (Suggested by Author(s)) } \\
\text { Oxygen sensors } \\
\text { Polarographic analysis } \\
\text { Space cabin atmospheres }\end{array}$ & $\begin{array}{l}\text { 18. Distribu } \\
\text { Un }\end{array}$ & - Unlimited & Sat. 54 \\
\hline $\begin{array}{l}\text { 19. Security. Classif. (of this report) } \\
\text { Unclassifled }\end{array}$ & $\begin{array}{l}\text { 20. Security Classif. (of this page) } \\
\text { Unclassified }\end{array}$ & $\begin{array}{l}\text { 21. No. of Pages } \\
26\end{array}$ & $\begin{array}{l}\text { 22. Price* } \\
\$ 3.75\end{array}$ \\
\hline
\end{tabular}

-For sale by the National Technical Information Service, Springfield, Virginia 22161 


\section{POLAROGRAPHIC OXYGEN SENSORS}

\section{TABLE OF CONTENTS}

Page

Introduction. . . . . . . . . . . . . . . . . . . . 1

Knowledge Contribution Previously Identified. . . . . . . . . . 2

I. What They Are .................... 2

II. Development History ................ . 2

III. Space Requirements--Contributions . . . . . . . . . 5

IV. Applications Impact/Significance. . . . . . . . . 7

A. Medical Applications ............ 7

B. Industrial Fermentation. . . . . . . . . . 13

C. Oceanography . . . . . . . . . . . . . 14

D. Wastewater and Sewage Treatment. . . . . . 15

E. Other Industrial Applications. . . . . . . . 16

F. Sport Fishing. . . . . . . . . . . . 17

Chronology. . . . . . . . . .............. 19 
How does new knowledge, acquired for one purpose, develop into useful technology having significant impact and benefits to society? This is one case study in a series of detailed investigations tracing the origins of new knowledge developed to solve specific problems of manned space exploration, and its subsequent modification and application to commercial needs.

What differences exist between the technology required for space exploration and the requirements for application to earthly problems? What factors determine the time required to convert new knowledge into viable economic benefits? Various case examples disclose differing patterns of technological development. By comparing the common and contrasting findings it may be possible to understand better how new knowledge generates real benefits.

Starting from a specific "knowledge contribution" previously identified from an analysis of astronaut life support requirements, the origins, adaptations, and eventual significance of the new technology are presented. 
POLAROGRAPHIC OXYGEN SENSORS

\section{Knowledge Contribution Previously Identified}

Early biomedical studies of space cabin atmospheres found that oxygen measuring instruments which could hold calibration and accuracy for periods up to 2 weeks were not available. Because of the importance of monitoring spacecraft atmospheres, new types of stable and reliable oxygen instruments were developed and space qualified before the first Mercury flights.

The new membrane-type oxygen sensors are inherently stable, and permit direct reading of oxygen in gas mixtures and in liquids. Polarographic oxygen monitors require only occasional calibration, and are small, rugged, and inexpensive enough for widespread use.

Space engineers anticipated potential applications in water pollution studies, and use as pocket size hypoxia warning devices for mine safety.

\section{I.. What They Are}

Modern oxygen sensors are small electrochemical cells capable of measuring the concentration of oxygen--either in gas mixtures, or as dissolved oxygen in water or blood. Oxygen analyzers make possible such a wide range of vital measurements in industry, medicine, and science, that their development has been called the most significant advance in gas analysis since 1950 .

\section{Development History}

The polarographic principle originated with Heyrovsky and the discovery of the dropping mercury electrode in 1922. Inorganic and analytical chemists made widespread use of the polarographic method, primarily for the determination of metallic elements. The 1959 Nobel Prize in Chemistry was awarded to Heyrovsky in recognition of the growing importance of polarographic analysis. 
Major trends and milestones in the subsequent evolution of oxygen measurement are depicted in Figure 1, and documented in greater detail in the chronology section.

As an improvement over the dropping mercury electrode, Kolthoff, in 1939, introduced the vibrating or rotating platinum microelectrode. The platinum electrode was better suited for the analysis of nonmetallic and organic constituents; however, rapid polarization or poisoning of the platinum surface limited its use in water solutions. Kolthoff was also the first to determine the reactions of oxygen at the platinum electrode. Many attempts were made over the next 15 years to stabilize the fine platinum wire probes which would be so convenient in biology and medicine. Various coatings were applied to the surface of the platinum electrode, but the goal of a stable reproducible sensor proved elusive. Brubaker's classic study of oxygen permeation through polymers and packaging films suggested a slightly different approach .

Dr. L. C. Clark, Jr., biochemist and medical researcher, provided the key breakthrough. In 1956, Clark reported the use of a polyethylene membrane over the platinum electrode as a simple and continuous monitor to record blood oxygen in the heart-lung machine. Although this development was reported in the relatively obscure journal, Transactions of the American Society of Artificial Internal Organs, the significance of the discovery was soon recognized in fields as diverse as oceanography, wine-making, and instrumentation. Clark's patent issued in 1959, and rights were assigned to Beckman Instruments, Inc., where the oxygen sensors had been under development for more than 2 years.

The earliest applications of polarographic oxygen sensors dealt with dissolved oxygen measurement. Polarography had traditionally been carried out in liquids. The initial developments and applications of the sensors involved blood oxygen, tissue metabolism, and microbiology. The stage was now set for dramatic advances in the analysis of gas mixture.

The rapid, accurate, and continuous measurement of oxygen in gases had presented problems for a number of years. The standard method, the Winkler Titration, is a time-consuming wet titration, requiring trained chemists with considerable experience in this laboratory method. The paramagnetic analyzer, introduced by Linus Pauling in 1940, was one of the preferred instruments. The magnetic analyzer was rugged and simple, but required a visual reading and had a single, narrow range. There still was no totally satisfactory oxygen-measuring instrument available as late as the $1950^{\prime}$ s.

In preparation for NASA's manned space missions, which called for cabin atmospheres of pure oxygen at 3 to 5 psi pressure, the school of Aviation Medicine conducted a series of studies using space cabin simulators. 


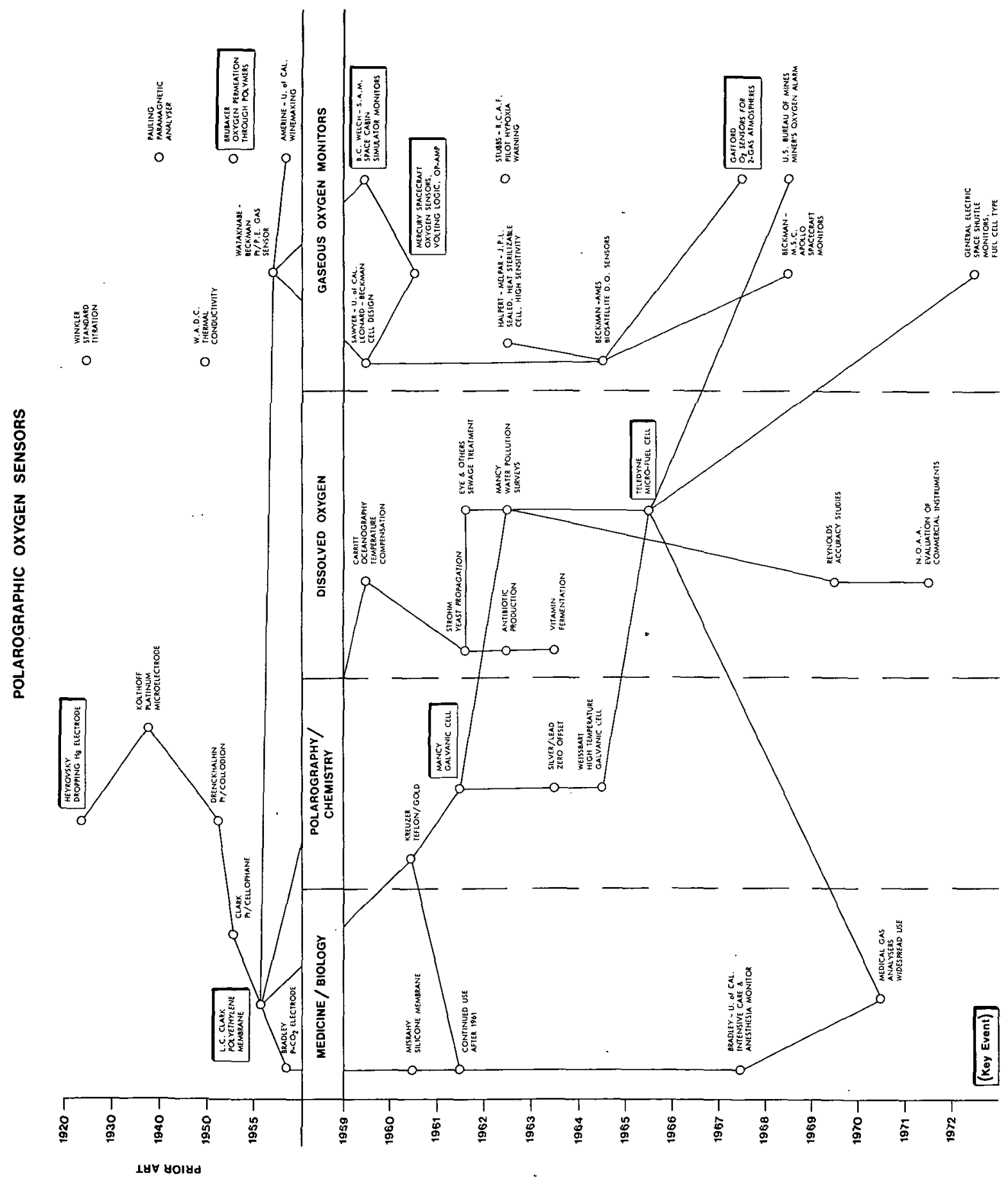


While the requirements for simulator-oxygen monitoring instruments were less demanding than those for flight instrumentation, the most difficult characteristic to obtain was sensor stability--the ability to maintain calibration and accuracy for the duration of the simulation study, often 15 to 30 days.

While still under development, the new polarographic sensors were tested as monitors during experiments to determine human response to artificial atmospheres for space.

Following these studies, the Mercury spacecraft oxygen monitors were developed and built by Beckman Instruments, Inc. In addition to longterm stability, the requirements for spacecraft atmospheric monitors presented many challenges that could not be satisfied by currently available instruments. The major space requirements for oxygen monitors are summarized in Figure 2. The fragile, complex, and often temperamental instruments used in medicine and analytical chemistry were not suitable for NASA's space measurements.

Two distinct types of oxygen sensors evolved to meet different needs. The voltametric membrane electrodes (clark) employ a battery to polarize the indicator electrode, and require a stable, high-gain DC amplifier to measure the electrode output. This type of sensor can be made as small as required, for example, to fit inside a human artery. The second type, a galvanic membrane electrode, first used in Europe, was introduced by Mancy in 1961. Galvanic or "fue1-cel1" sensors use the oxygen reaction at one electrode of a cell to generate current that can be measured with a simple microammeter. Analyzers using galvanic sensors produce strong signals from large electrodes, and are more suited for field studies such as pollution measurements. Oxygen fuel-cell development for space flight application made significant contributions that culminated in the selection of fuel-cell type atmospheric monitors for the current Space shuttle program.

In the course of both manned and unmanned space missions, oxygen monitoring systems were developed for NASA which not only met the extreme requirements necessary for probes of planetary atmospheres, but also satisfied the general requirements for most earthbound instrumentation. The technical advances in oxygen instrumentation during the early 1960's made possible a wide variety of applications and uses which had been inconvenient or not feasible until compact, reliable, stable sensors and associated electronics had been proved in the rigors of various space programs.

\section{Space Requirements--Contributions}

The crucial decision to use a pure oxygen atmosphere at reduced pressure was made early in the manned space program. Oxygen tension in the 


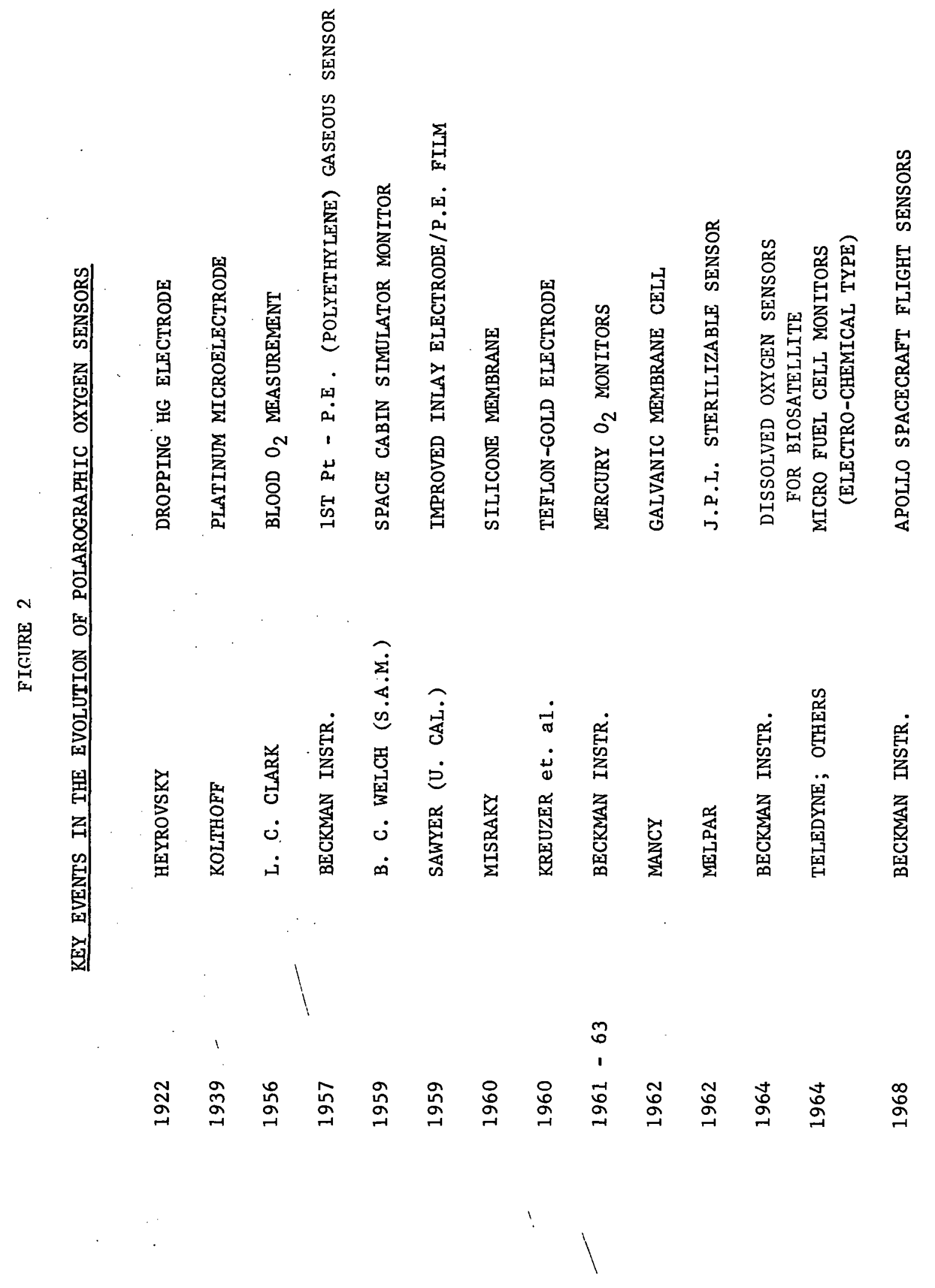


cabin atmosphere had to be continuously monitored. The major requirements for spacecraft oxygen analyzers are shown in Table 1 , together with the characteristics and limitations of the available analyzers. Cabin oxygen levels had to be telemetered to mission control. The sensors had to be capable of maintaining calibration from preflight check to final splashdown, without drift, temperature effects, or attention from the crew.

To satisfy these requirements, a variety of innovations were - required. Sensor cells were redesigned and sealed to extend working 1 ife. (Similar sealed electrodes are now routinely used in oceanographic studies to depths beyond 4,000 meters.) Operational amplifiers and integrated circuit signal conditioners replaced earlier DC amplifiers that were prone to drift. Three sensors were combined in a voting logic circuit--where two of the three cells must agree on the $\mathrm{O}_{2}$ reading. The advances and improvements developed for spacecraft monitors also satisfied many of the requirements for oxygen measurement on earth. For example, the heat-sterilizable sensors needed for planetary probes helped make practical improved fermentation $\mathrm{O}_{2}$ sensors which must be designed to withstand steam sterilization.

Some of the significant contributions to oxygen analyzer technology are listed in Table 2. Requirements that benefited from manned space flight instrument development are indicated, and the extent of some advances made during the 1960 's are shown.

\section{Applications Impact/Significance}

The enormous range of applications developed for oxygen sensors is the most striking aspect of the new technology in this case study. The diversity of usage is matched by the importance of benefits derived from this new capability. Principal fields of application are listed in Table 3 .

\section{A. Medical Applications}

From the initial use of a polarographic membrane sensor in the monitoring of blood oxygenation in the heart-lung machine for open-heart surgery, the range of medical applications has multiplied. The equipment associated with the basic sensor cells is by now quite specialized and sophisticated.

A partial listing of major types of clinical, surgical, diagnostic and therapeutic analyzers that employ voltametric or galvanic oxygen sensors as the basic element includes:

- In-1ine anesthesia gas monitors

- Blood gas analyzers for $\mathrm{PO}_{2}, \mathrm{PCO}_{2}, \mathrm{PH}$ 


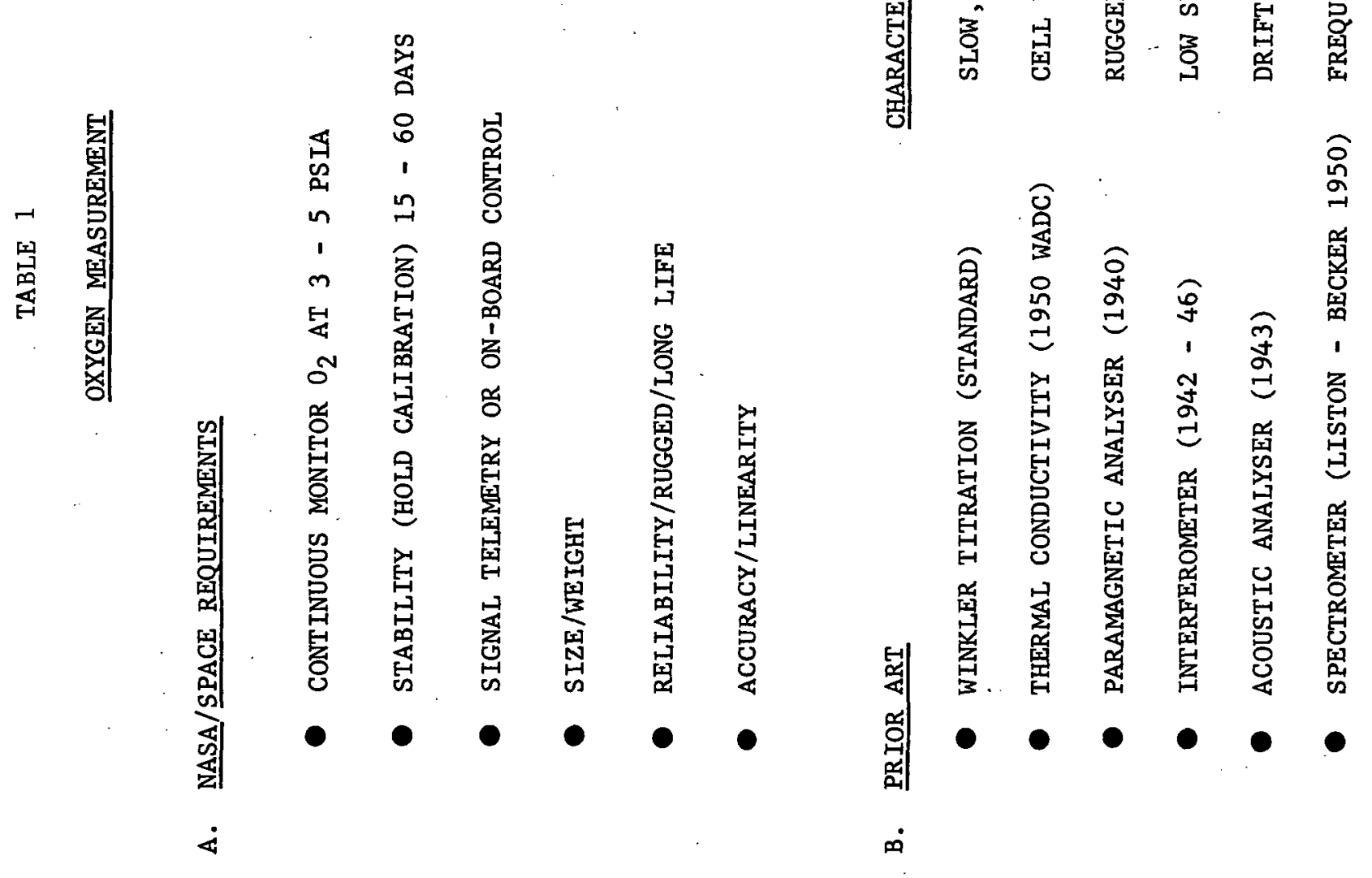


봉

蓾

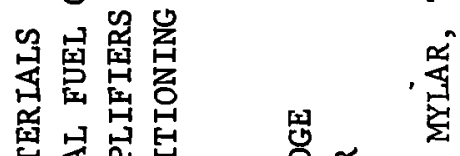

这热是

똔동

娄造 웅

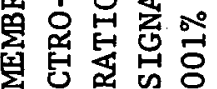

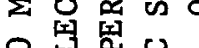

응 武嵒号
음

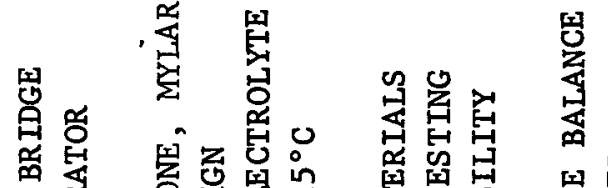

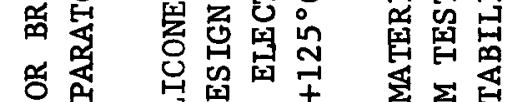

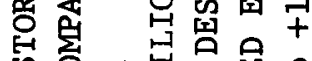

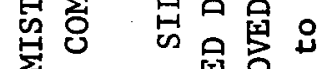
的国。

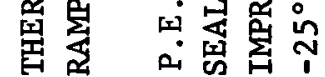

岸它

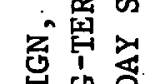

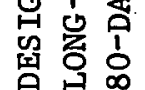

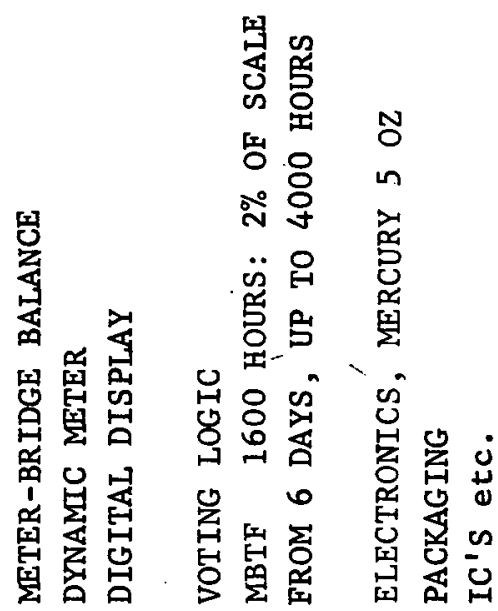

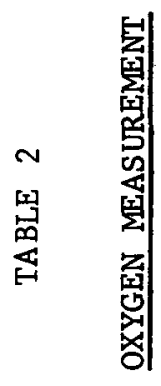

동.

क 㬅

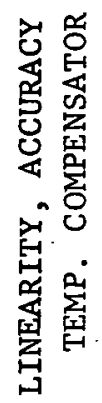

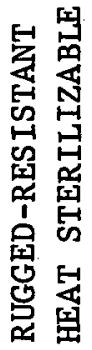

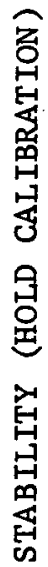

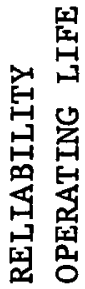

密器 


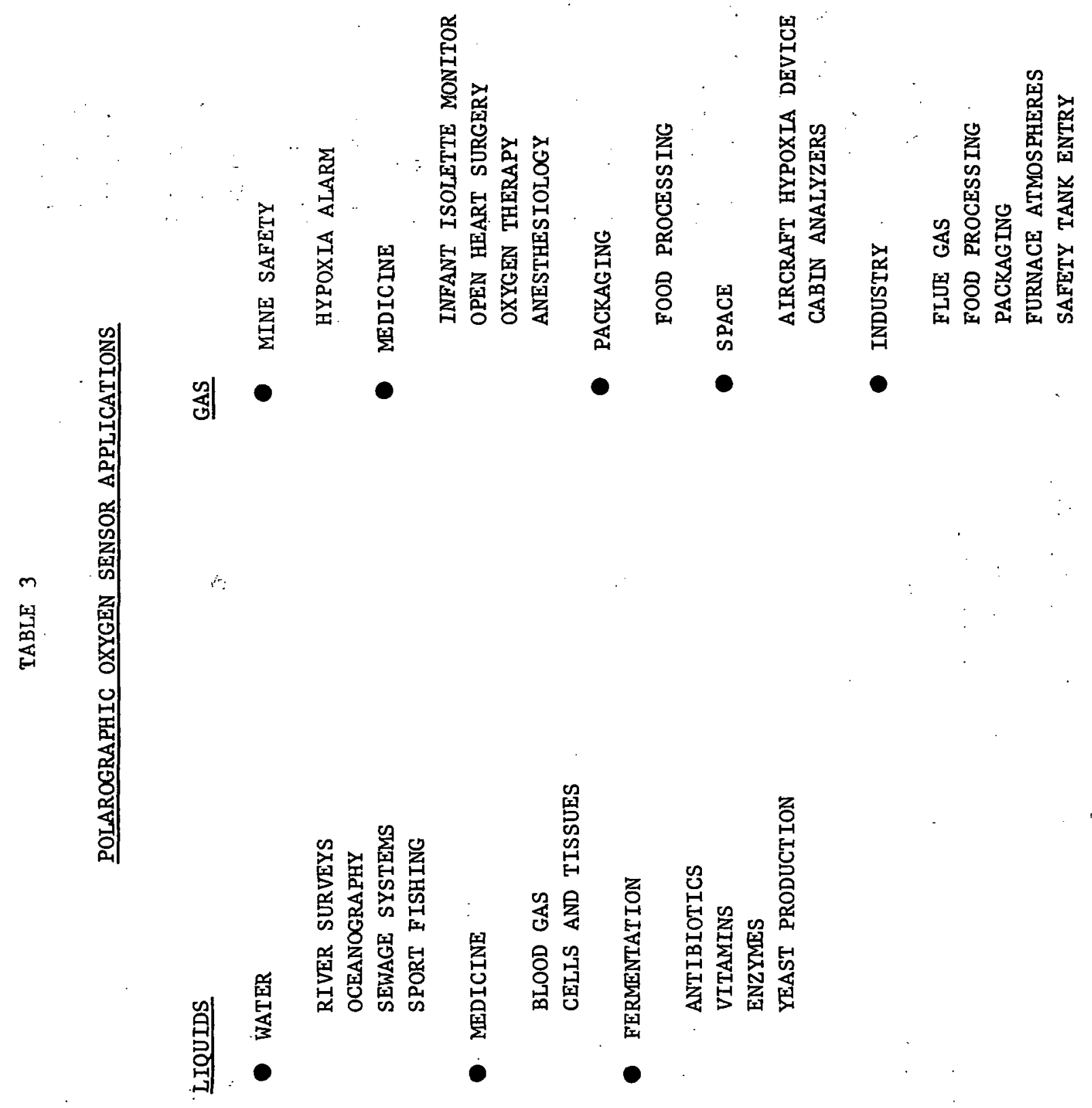


- Oxygen-therapy tent monitors with Hi/Lo alarms

- Differential oxygen meters (each meter uses two sensors)

- I.P.P.B. respirator monitors

- Infant isolette monitor with fail-safe alarm

- Combination ventilator/nebulizer therapy units

- Flow-through blood-oxygen probes for extra-corporeal shunts

- Infant incubator cyclic (Mix-Box) oxygen controller

(Equipped for programmed "weaning" to lower $\mathrm{O}_{2}$

- Portable gas monitor with strip chart recorder

- Hypodermic needle or catheter mounted in vivo $\mathrm{PO}_{2}$ probes

- Oxygen consumption computers for cardio-pulmonary function

- Remote-reading, intensive-care unit monitors

Medica1 applications of oxygen measuring electrodes are the most numerous, and are undoubtedly the most vital. Cardiac arrests in the operating room are often a direct consequence of inadequate oxygenation during delivery of the anesthetic gas mixture. Today, anesthetic gas monitors indicate the precise concentration of oxygen flowing to the patient breathing mask. At the same time, blood-gas analyzers report the actual oxygen level of the patient's bloodstream.

Postnatal care of infants has been made safer through the use of air-oxygen mixture controllers. As shown in the following picture (Figure 3 ), these can be programmed to deliver the prescribed, gradually declining levels of oxygen. The time-consuming and sometimes dangerously inaccurate practice of manual adjustment of oxygen flow-rates is now unnecessary.

In 1973, some 28 manufacturers of medical instrumentation shipped polarographic oxygen measuring and controlling units valued at more than $\$ 12$ million. The use of blood-gas analyzers is presently increasing at the rate of 21 percent annually. Oxygen therapy and respiration-monitoring analyzers represent the largest and fastest growing medical application. Hospital usage of such units increased from $\$ 2.7$ million in 1971 , to nearly $\$ 6$ million in 1973. Applications are expected to require some $\$ 11$ million in therapeutic oxygen analyzers by 1975 . 


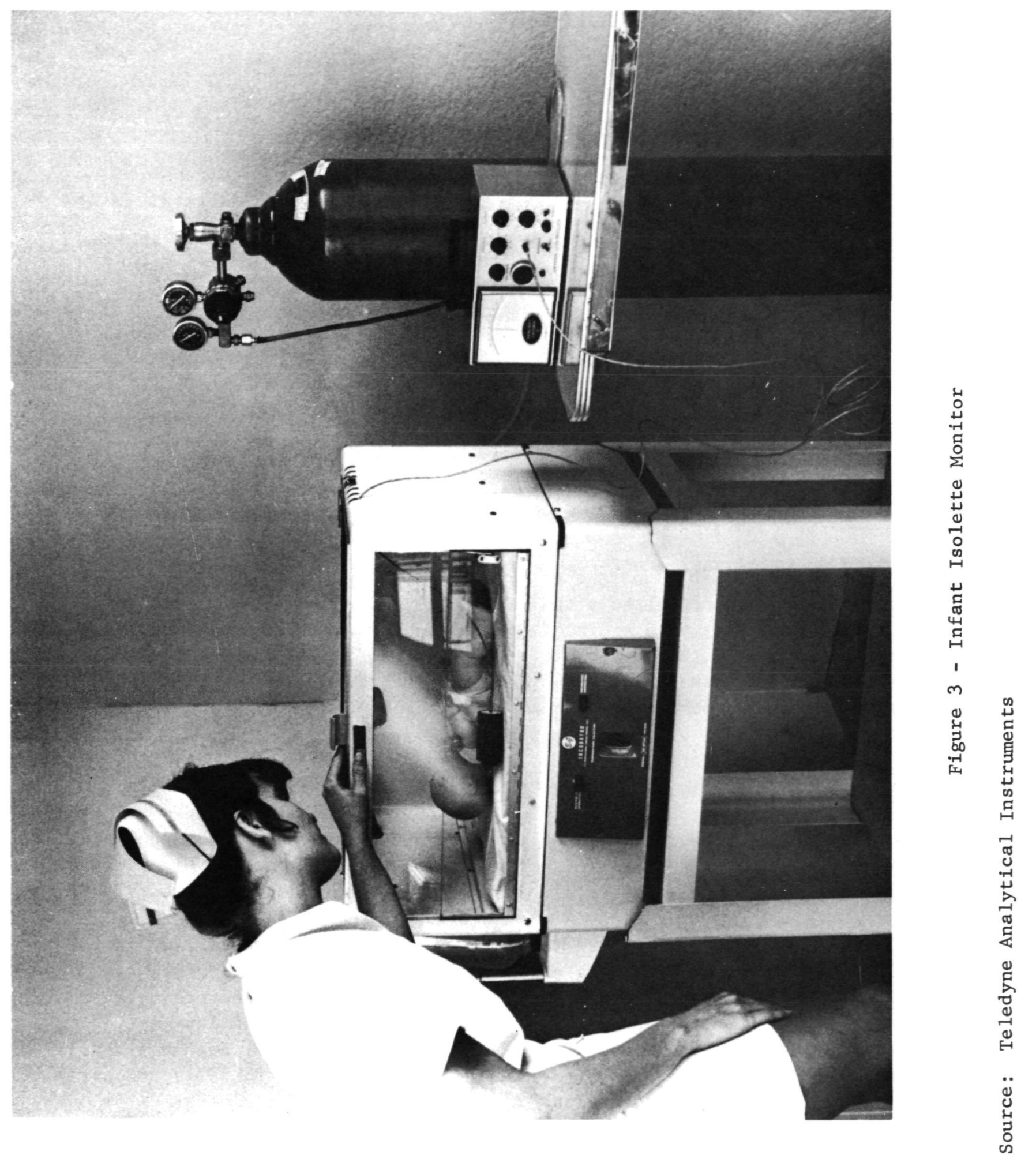


The true value of this recently developed technology can only be gaged in terms of the new dimensions of safety, confidence and reliability added to medical care.

\section{B. Industrial Fermentation}

More than 34 companies in the United States are engaged in producing antibiotics, vitamins, enzymes and other high-value products through controlled fermentation. The importance of maintaining optimum aeration during aerobic fermentation is well known. The rate of oxygen transfer to the medium and uptake by the microorganisms being cultured may affect the direction of metabolism (often with damaging effects), as well as influencing the rate of product formation. Maintaining the optimum levels of oxygen throughout the fermentation leads to higher yields and increased activity. However, oxygen requirements vary during different stages of production, so that aeration rates must be adjusted to match metabolic demand.

The most direct and useful index of proper aeration is the continuous measurement of dissolved oxygen. The availability of polarographic oxygen sensors capable of being steam sterilized in fermentation tanks permits control.over aeration so that increased cell mass and higher potency can be attained. Oxygen monitoring also avoids undesirable over-aeration and reduces the cost of chemical antifoam additives.

Major products produced by industrial fermentations include:

- Antibiotics for drugs

- Antibiotics for feed supplements

- Riboflavin

- Vitamin $\mathrm{B}_{12}$

- Amino acids

- Yeast propagation

- Enzymes

$$
\begin{aligned}
& \text { fungal amylases } \\
& \text { glucose isomerase } \\
& \text { amyloglucosidase }
\end{aligned}
$$

Citric acid 
- Other acids

- Gilbere11ins

The value of shipments of these products aggregated nearly $\$ 900$ million in 1971 with the industry growing at 8 percent annually. Even modest improvements in output and activity derived from more precise fermentation control has great value.

\section{Oceanography}

One of the first and most valuable applications of polarographic oxygen instruments was in studying dissolved oxygen levels in estuaries and the open seas.

When oceanographers study the structure, mass movements and biological production potential of the oceans, the most important variables are water temperature, salinity and dissolved oxygen--as they change with depth. Dissolved oxygen was the one variable that could not be continuously measured. Now with the application of probes incorporating polarographic oxygen sensors, a continuous profile of dissolved oxygen can be recorded. Changes in oxygen levels are especially important to the marine biologist, since areas of abundant marine plant life can be charted, and zones where high nutrient levels have depleted dissolved oxygen can be studied.

Convenient and continuous monitoring of oxygen content in our coastal waters, bays and oceans can be of great economic significance through helping to develop U.S. marine resources and domestic fisheries. Proper conditions of oxygenation are especially critical in waters where shellfish are commercially taken. Sound management of offshore fishing grounds and increased exploitation of untapped open seafish stocks would stimulate growth of the U.S. fishing industry, and could provide important added sources of vitally needed food, fats and proteins.

New sewage treatment plants for nearly 40 million people must be built in coastal regions of the U.S. in the next 25 years. Both the construction and operating costs of these plants can be reduced appreciably if the capacity of coastal waters to assimilate and diffuse the treated wastes was better known. This will require detailed oceanographic study, with special attention to currents, oxygen replenishment rates, and photosynthetic activity in coastal waters. Thus, polarographic oxygen instruments which have evolved from NASA's manned flight programs may have a long and useful lifetime in environmental and oceanographic applications. 


\section{Wastewater and Sewage Treatment}

Significant improvement in the level of treatment of municipal sewage and industrial wastes is mandatory if the U.S. is to achieve its water pollution abatement goals. The expenditures required to meet reasonable effluent standards will be at least $\$ 60.8$ billion--about $\$ 21$ billion for industry, and $\$ 39$ billion for municipalities. Effluents discharged by many older plants far exceed the standard because of overloading and primitive process control.

Regardless of the type of waste, the biological process consists largely of providing dissolved oxygen for growth of the microorganisms that destroy the waste. Dissolved oxygen is, therefore, the most important single parameter in maintaining a stable and properly functioning treatment process. Continuous monitoring of dissolved oxygen at various points throughout the plant, and semiautomatic controls based on oxygenation and associated key process variables can assure effective sewage plant operation.

Polarographic oxygen sensors were first investigated in 1961 as an aid to waste treatment. Commercial versions of dissolved oxygen meters and biochemical oxygen demand instruments suitably adapted for sewage and wastewater measurements became available in 1967. ' Together with other advanced instruments and controls, oxygen measuring devices are today contributing to better waste treatment and more economical operations of sewage and waste treatment plants:

A11 types of wastewater instruments, and especially oxygen sensor based meters and analyzers, are proving their value through better waste treatment. In 1973, operators of waste treatment plants installed $\$ 2.1$ million worth of continuous oxygen monitors and controllers, portable dissolved oxygen meters and BOD measuring equipment.

Meters and control equipment currently represent on $1 \mathrm{y} 1$ percent of the total cost of waste disposal systems. However, oxygen analyzers permit superior treatment at lower cost, and installation of oxygen instruments in waste treatment plants is more than tripling each 5 years. This trend is shown in Table 4, showing expenditure patterns for waste treatment plants to 1980 . 
TABLE 4

WASTEWATER DISPOSAL PLANT EXPENDITURES--

MUNICIPAL AND INDUSTRIAL

(Mi11ions of dollars)

\begin{tabular}{|c|c|c|c|c|c|}
\hline & 1965 & 1968 & 1970 & 1975 & $\underline{1980}$ \\
\hline Treatment Plant, tota 1 & 542 & 742 & 900 & 1,564 & 2,420 \\
\hline Treatment Equipment & 77.0 & 116.9 & 183.9 & 353 & 687 \\
\hline Meters and Controls & 8.53 & 9.42 & 18.00 & 38.56 & 76.87 \\
\hline Dissolved Oxygen Instruments & 0.0 & 0.233 & 0.994 & 3.860 & 11.530 \\
\hline
\end{tabular}

Specific benefits derived from the use of modern oxygen measuring instruments and controllers for sewage and waste treatment include:

- Ability to accommodate higher organic loads, and better regulate or level-out slug loads, thus maintaining stable process conditions.

- Substantial improvement in effluent quality, and better control over the impact on downstream quality of receiving waters.

- Optimum closed-1oop control of surface and submerged aeration, providing maximum removal of organics at lowest operating cost.

The evolution of accurate, stable oxygen measuring sensors is but one example of new technology that can reduce the ultimate cost of achieving pollution control.

\section{E. Other Industrial Applications}

The convenience, speed and accuracy of polarographic oxygen sensors has led to the development of an impressive array of applications in industry. Industrial analyzers differ from most other instruments in requirements for stability, rugged packaging and extreme sensitivity at low oxygen levels. Techniques pioneered by Jet Propulsion Laboratory and Melpar in 1962 significantly extended the sensitivity and linearity of gas-phase sensors into the parts per million range for oxygen. Similar sensor designs are used today in trace oxygen analyzers for food packaging, semiconductor crystal growth, refinery catalyst regeneration and boiler feedwater analysis (at parts per billion $0_{2}$ ). 
Representative industrial uses include:

- Chemica1 process oxygen controllers

- Boiler combustion firebox monitors

- Flue gas analyzers

- Inert gas food packaging and processing

- Refinery catalyst regeneration

Catalytic reforming

Hydrocracking

- Liquid air fractionation/welding gases

- Lamp manufacture

- Oxygen steelmaking processes

- Furnace atmospheres, heat treating and anealing

- Semiconductor crystal growth

- Personal safety - tank entry monitors

\section{F. Sport Fishing}

Increasing use of dissolved oxygen meters for water quality studies in lakes and streams led to the marketing of similar instruments for the 33 million freshwater fishing enthusiasts. This inexpensive oxygen "Sentry" can locate the water strata frequented by various species of gamefish-especially bass.

Related uses of professional oxygen monitors include fish farming and mariculture. In fish hatcheries the oxygenation of spawning tanks is critical, and unless the highest practical oxygen levels are maintained, many species will not breed, or hatch mortality may be excessive. 
Principal Suppliers of Membrane-type Oxygen Monitors, Instruments and Sensors.

Applied Electrochemistry, Inc.

Bass-0x, Inc.

Beckman Instrument, Inc.

Bio Marine Industries

Bourns, Inc.

ChemePec, Inc.

Chemtrix, Inc.

Chemtronics, Inc.

Clinical Analysis Products Co.

Delta Scientific

Dover

Draeger Normalair

Ecologic Instrument Corporation.

Electro-Nite Co.

Fermentation Design, Inc.

Foregger Co., Inc.

Gilson Medical Electronics, Inc.

Gottscho, Inc.

General Scientific Equipment Co.

Honeywe 11

Horizon

Hydrolab Corporation

International Biophysics Corp.

LKB Medical AB

London Co.

National Research Development Corporation

New Brunswick Scientific Co., Inc.

Ohio Medical Products

Precision Scientific Co.

Sensorlabs

Sentry

Sinclair Scientific, Inc.

Technology, Inc.

Teledyne Analytical Instruments

Thermaco Instruments Co.

United Technical Corporation

Universal Interloc, Inc.

Waters Instruments, Inc.

Weston and Stack, Inc.

WTW GmbH

Yellow Springs Instruments Co. 


\section{CHRONOLOGY}

\section{STABLE POLAROGRAPHIC OXYGEN SENSORS}

1922: Heyrovsky, discovery of polarographic principle, dropping Hg electrode. Received 1959 Nobel Prize for his work.

1939: Kolthoff used vibrating or rotating platinum microelectrodes primarily to study organic reactions. The number of papers on polarography had reached more than 500 by 1940 . Activity peaked in 1939, but continued at 150 per year to 1945 , then shot up to 950 per year by 1955 .

$1950-$

1951: Morgan and Nahas, tried rotating platinum electrode coated with silicone fluid. Unsuccessful.

1951: Drenckhalhn used Pt electrode coated with Collodion. Better than oilfilms .

1953: Brubaker and Kammermeyer, key study on oxygen permeation through thin polymeric films. Ind. Eng. Chem., 45, 1148 (1953).

1953: L. C. Clark, J. App1. Physiology, 6, 189 (1953) cellophane/platinum electrode for blood $\mathrm{PO}_{2}$.

1956: L. C. Clark, Trans. Am. Soc. Art. Organs, 2, 41 (1956), first discuss the use of polyethylene membrane; lag time several seconds, temperature correction $\pm 1.5 \%$.

1957: Wataknabe \& Leonard (Beckman) used Pt electrode against polyethylene membrane, with internal silver chloride electrode and saturated KCL as a reference electrode.

1958: M. A. Amerine (U. Cal. Davis) used Beckman (Wataknabe) method (based on Clark's Work) to determine $\mathrm{O}_{2}$ in wine. Electrode stable for several days. Food Engineering, 744-748 (1958).

1958: Kreuzer et. al., catheter electrode for blood oxygen. Use of Teflon membrane which gave higher current output. J.App1. Physiology, 13, 65 (1958).

1960: Neville (S.A.M. USAF), used classical polarographic method to modify Van Slyke procedure. No mention of membrane electrodes. J. Appl. Physiology, 15, 717 (1960). 
1959: B. C. Welch (S.A.M.), atmospheric studies for NASA space cabins.

1959: Carritt, John Hopkins Department oceanography and Chesapeake Bay Institute; first reported use of thermistor compensation for temperature. Designed a single unit sensor with lower output impedence, capable of use with conventiona1 recording equipment. Operates 24 hours with no drift. Anal. Chem, 3, 2 (1959).

1959: L. C. Clark, Jr., U.S. Patent 2,913,386, application March 1956, claims a polarographic cell for use in analyzing oxygen. Assigned to Beckman Instrument Company.

1959: Sawyer et.a1., (U. Cal. Riverside), modifications of Wataknabe electrode, Beckman Instruments Inc., Grant. John Leonard of Beckman Advisor.

1960: Beckman, subcontract to develop Mercury spaceraft $\mathrm{O}_{2}$ sensors.

1960: Yellow Springs Instrument Company offered commercial version of Clark electrode. (Polger et. al.).

1960: Beckman Instruments Inc, electrodes bulky, require high-gain, driftfree D.C. amplifier; Misrahy et. a1., J. App1. Physiology, 199, 959 (1960).

1961: Beckman Instrument Company announces polarographic oxygen sensor designed for use with the manufacturer's airborne high impedence amplifier.

1961: Strohm (Red Star Yeast), dissolved oxygen measurement in yeast propagation using Beckman Pt/P.E., control of oxygen in antibiotic and vitamin fermentations affects the direction of metabolism of microorganisms, as well as the rate of product formation.

1961: Eye et. a1., (UHPHS grant), Water and Sewage Works, 108, 231 (1961), Beckman electrode used to measure BOD and DO in sewage treatment. Reproducibility good, temperature dependent, zero drift due to battery, 1-3 minutes to stabilize response, 3-4 mil. P.E. membranes most satisfactory, electrode needs service 3-4 times per year.

1961: Weissbart and Ruka, high temperature galvanic cell oxygen gage. Rev. Sci. Inst., 32, 593 (1961).

1962: Stubbs (RCAF), polarographic hypoxia warning sensor for air crews using Beckman electrode, Aerospace Medicine, 33, 209 (1962). 
1962: Chemtronics (San Antonio), GP-10 gas phase oxygen transducer, gold electrode in rugged design to withstand high levels of shock and gravity loading, units checked down to $50 \mathrm{~mm}$. Hg total air pressure, holds $1 \%$ accuracy for long term.

1962: Mancy and Westgarth, J. Water Pollution Control Foundation, 1037, (1962), adapted the galvanic cell principle using silver-lead couple for water pollution studies.

1962: Halpert (Melpar), sensor that can be heat sterilized at $145^{\circ} \mathrm{C}$ for 24 hours. Sensitive to $0.001 \%$, response time 30 seconds, stable for unattended operation for 2 months, NASA-CR-50605.

1962-

1963: Halpert (Melpar), investigated over 60 membranes to get high sensitivity for gas phase oxygen sensor for $\left(-25^{\circ}\right)$ low temperature, low pressure measurement of $0_{2}$ to $0.001 \%$ concentration. NAS-7-100 J.P.L. contract 950284, J. Electroanalytical Chemistry, 6, 426 (1963).

1964: Beckman Instruments Inc., flight $\mathrm{O}_{2}$ sensors for Biosatellite dissolved oxygen. NAS-2-1549, (Ames Res. Center).

1965: NASA Tech Brief 65-10066 March 1965, low temperature $\mathrm{H}_{2}-\mathrm{O}_{2}$ fuel cell is described as an oxygen detecting monitor.

$1965-$

1969: Teledyne Analytical Instruments Micro-Fuel Ce11, U.S. Patent 3,429,796 Maintenance free, disposable sensor. Absolute zero, long life, longterm stability, specific for oxygen.

1967: Bradley (U. Cal. S. F., Cardiovascular Research) reports development of rugged analyzers a) for routine use in the intensive care unit, and (b) anesthesia, Biomedical Sciences Instrumentation, 3, 181 (1967).

1967: Weissbart and Smart (Applied Electrochemistry, Inc.), "Study of Electrolytic dissociation of $\mathrm{CO}_{2}-\mathrm{H}_{2} \mathrm{O}$ using a solid oxide electrolyte." NASACR-680 (1967).

$1967-$

1968: Gafford (Beckman Instruments, Inc.), "Oxygen Partial Pressure Sensors for Two-gas Atmospheres," Space/Aeronautics (February 1968), p. 95; al1 post-Apollo manned spacecraft will use two-gas atmospheres, life of sensor 10-14 weeks, limited by (a) exhaustion of KCL gel and (b) dry out of gel. Under humid conditions life is much longer, stable for several weeks ( 81 days), small volume, low weight, low power consumption, relatively low cost, 5 oz complete, MTBF more than 1,590 hours for $\pm 2 \%$ of full-scale deviation. 
1968: Beckman Instruments Inc., "F1ight Oxygen Sensors Apollo Spacecraft," NAS-9-8148 (M.S.C.).

1968: Bowser (U. S. Bureau of Mines), "Miniature Oxygen Deficiency Alarm" B.M.I.C. No. 8358 (1968), used Teledyne electrochemical cell in pocket alarm unit having two warning tones adjustable within 10-21 percent $\mathrm{O}_{2}$ range.

1969: Reynolds, J. Water Pollution Control Federation, 2002 (December 1969) comparison studies of Winkler vs. oxygen sensor.

1970: Le Fevre (Brookhaven National Lab), "Problems in Measurement of Tissue Respiration with the Oxygen Electrode," Bioscience, 20, 761 (July 1970), NASA-Grant 33-171-(001).

- 1970: Weissbart and Smart, "Development of a $\mathrm{CO}_{2}-\mathrm{H}_{2} \mathrm{O}$ Oxide Electrolyte Electrolysis System." NASA-CR-73464.

1971: Piyanowski (N.O.A.A.), "A Quantitative Evaluation of Dissolved Oxygen Instrumentation," AIAA Paper 71-1053 (1971).

Activity linked to aerospace requirements 
Special thanks is given to the following companies and their representatives for the information received during telephone interviews and literature review:

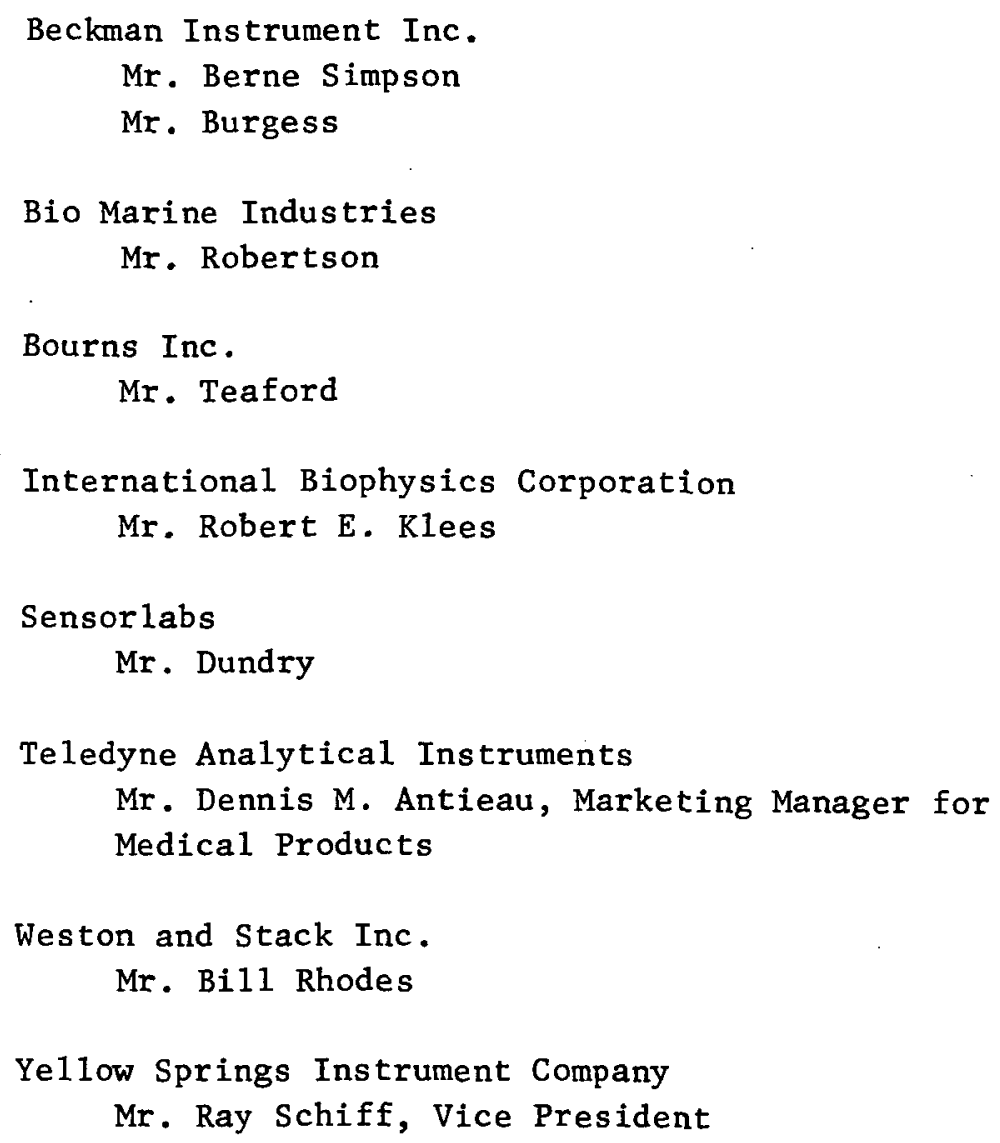


"The aeronautical and space activities of the United.States shall be conducted so as to contribute. . . to the expanision of buman knoul. edge of phenomena in the atmosphere and space. The Administration shall provide for the widest practicable and appropriate dissemination of information concerning its actitities and the results thereof."

- National Aeronautics and Space ACt of 1958

\section{NASA TECHNOLOGY UTILIZATION PUBLICATIONS}

These describe science or technology derived from NASA's activities that may be of particular interest in commercial and other non-aerospace applications. Publications include:

TECH BRIEFS: Single-page descriptions of individual innovations, devices, methods, or concepts.

TECHNOLOGY SURVEYS: Selected surveys of NASA contributions to entire areas of technology.

OTHER TU PUBLICATIONS: These include handbooks, reports, conference proceedings, special studies, and selected bibliographies.

Details on the availability of these publications may be obtained from.

National Aeronautics and

Space Administration

Code KT

Washington, D.C. 20546
Technology Utilization publications are part of NASA's formal series of scientific and technical publications. Others include Technical Reports, Technical Notes, Technical Memorandums, Contracior Reports, Technical Translations, and Special Publications.

Details on their availability may be obtained from:

\section{NATIONAL AERONAUTICS AND SPACE ADMINISTRATION Weshington, D.C. 20546}

